Short reports

\section{Serum or urinary amylase estimations in children with acute abdominal pain}

Acute abdominal pain occurs commonly in children and is one of the most frequent causes of hospital admission. Many children are sent into hospital with the diagnosis of acute appendicitis; however, in many children the pains resolve without treatment. Even if other causes of abdominal pain are excluded, a large group still remains without obvious organic cause. Apley (1975) believes that recurrent acute abdominal pain has a psychosomatic basis in most children. During a study into hereditary pancreatitis several patients were found who had been diagnosed as having nonorganic abdominal pain and later proved to have had recurrent pancreatitis (Sibert, 1975). Because of this background an attempt was made to estimate the frequency of pancreatitis in children with idiopathic abdominal pain by serum or urinary amylase estimations.

\section{Methods and results}

100 children admitted with acute abdominal pain to Llandough Hospital, Penarth, S. Glamorgan, in 1975 were studied. Children with a definite diagnosis such as acute appendicitis were excluded. Llandough Hospital takes paediatric admissions from the west half of Cardiff and the Vale of Glamorgan. In the majority of the 100 children blood was taken on admission by venepuncture for serum amylase estimation. Blood is usually taken for full blood count in such children so no extra venepuncture was needed. In 8 children blood was not taken and urinary amylase estimation was performed. Serum and urinary amylase estimations were performed using standard techniques. The laboratory's normal upper limit for serum amylase is $300 \mathrm{IU} / 1$, and for urinary amylase $1300 \mathrm{IU} / 1$.

Fifty boys and 50 girls were studied; mean age was $10 \cdot 1$ years. The youngest patient was 4 years old and the oldest 15 years, with a standard deviation of 2.4 years. 4 children had serum amylase levels above the laboratory's normal of $300 \mathrm{IU} / 1$. In 3 of these children the levels were only marginally raised $(315,360$, and $310 \mathrm{IU} / \mathrm{l})$. It was not thought that these children had pancreatitis. Another patient, a 15-year-old girl, had a serum amylase of $1400 \mathrm{IU} / \mathrm{l}$. She had diabetes mellitus diagnosed when she was 9 years old and had been on insulin since then. She was admitted with a history of 9 hours of abdominal pain and vomiting. On examination she had generalized abdominal tenderness and guarding. In addition to her raised amylase level investigations showed a blood glucose of $6.8 \mathrm{mmol} / 1(123 \mathrm{mg} / 100 \mathrm{ml})$, serum bicarbonate $18 \mathrm{mmol} / 1(18 \mathrm{mEq} / \mathrm{l})$, and serum lipase of 1.5 Sigma-Teitz units (laboratory normal up to 0.5 units). Her pain settled over 2 days.

\section{Discussion}

Serum or urinary amylase estimations are not entirely satisfactory methods of excluding pancreatitis. Both may not be raised in pancreatitis, and serum amylase may be raised in other conditions. Nevertheless, these estimations seemed to be the only practical methods available. Although serum amylase may be raised in diabetic ketoacidosis (Knight et al., 1973), diabetes mellitus appears to be a cause of pancreatitis in children (Malone, 1974). In the 15-year-old girl with a serum amylase of 1400 units in this series the high amylase level, the mild nature of the acidosis, the raised serum lipase and the clinical story made pancreatitis the likely diagnosis.

This survey confirms that pancreatitis is an uncommon cause of acute abdominal pain in childhood with only one case in 100 children having been found. However, it is common enough to warrant blood being taken for a serum amylase estimation under certain conditions: particularly if the pain is epigastric, if there is a suggestive family history, or if there is a known predisposing factor such as trauma (Adams et al., 1966) or cystic fibrosis (Shwachman et al., 1975).

\section{Summary}

Serum or urinary amylase was measured in 100 children admitted to hospital with acute abdominal pain in whom no definite diagnosis was made. 4 children had serum amylase levels above the laboratory's upper limit of normal (300 IU); however, in 3 of the children the level was only marginally raised and they were not thought to have had pancreatitis. A 14-year-old diabetic girl had a 
serum amylase level of $1400 \mathrm{IU} / \mathrm{l}$ and was thought probably to have had pancreatitis. It is concluded that while pancreatitis is an unusual cause of abdominal pain in childhood, it is common enough to warrant a serum amylase estimation if the pain is epigastric or if there is a known predisposing cause.

I thank Mr. B. D. Spragg and staff at the Biochemistry Department, Llandough Hospital for performing the serum amylase estimations, and Drs. P. T. Bray, E. N. Thompson, and E. R. Verrier Jones for allowing me to study the patients under their care.

\section{References}

Adams, J. T., Elebute, E. A., and Schwartz, S. I. (1966). Isolated injury to the pancreas from non-penetrating trauma in children. Journal of Trauma, 6, 86-98.

Apley, J. (1975). The Child with Abdominal Pains, 2nd ed., p. 33. Blackwell, Oxford.

Knight, A. H., Williams, D. N., Ellis, G., and Goldberg, D. M. (1973). Significance of hyperamylasaemia and abdominal pain in diabetic ketoacidosis. British Medical Journal, 3, 128-131.

Malone, J. I. (1974). Juvenile diabetes and acute pancreatitis. Journal of Pediatrics, 85, 825-827.

Shwachman, H., Lebanthal, E., and Khaw, K. T. (1975). Recurrent acute pancreatitis in patients with cystic fibrosis with normal pancreatic enzymes. Pediatrics, 55, 86-95.

Sibert, J. R. (1975). A British family with hereditary pancreatitis. Gut, 16, 81-88.

\section{J. R. SiBERT}

Department of Child Health, The Welsh National School of Medicine, Heath Park, Cardiff CF4 4XW.

\section{Influence of continuous positive airways pressure treatment on ductus arteriosus shunt assessed by echocardiography}

In preterm infants the incidence of patent ductus arteriosus (PDA) is high. According to Kitterman et al. (1972) $15 \%$ of infants with a birthweight under $1750 \mathrm{~g}$ have clinical and haemodynamic evidence of PDA. The combination of respiratory distress syndrome (RDS) and PDA is often seen (Siassi et al., 1969). By echocardiography it is possible to detect indirectly left-to-right shunting distal to the atrioventricular valves and to follow the effects of therapy on the shunt flow (Silverman et al., 1974).

We present a case where decreased shunt flow during treatment with continuous positive airways pressure (CPAP) was demonstrable in an infant with RDS and PDA.

\section{Case report}

A male infant was born as the first of twins in the 28th gestational week with a birthweight of about $900 \mathrm{~g}$; Apgar score was 1 and 5 at 1 and 5 minutes. He was ventilated for about 10 minutes, but then breathed spontaneously and had good colour. Both twins were immediately transferred to the Neonatal Intensive Care Unit.

During the first 24 hours he had apnoeic spells which increased in frequency. Chest $x$-ray showed a reticular-granular pattern suggestive of hyaline membrane disease. Treatment with CPAP applied with a face chamber was initiated and he improved. After 3 days of CPAP treatment he deteriorated with frequent apnoeic spells and intermittent positive pressure ventilation (IPPV) was necessary for 12 days. Thereafter he was weaned off IPPV and treated with CPAP only. In the following 4 weeks several attempts were made to take him off CPAP treatment, but each time he developed signs of cardiac decompensation with cyanosis, breathing difficulties, and hepatomegaly, signs that all disappeared as soon as CPAP was reinstituted.

At one week of age a systolic murmur was heard and repeat chest $x$-rays showed increased cardiac size and dilated pulmonary arteries. Digitalis treatment was started when he was 3 weeks old. At 41 days of age the systolic murmur disappeared and CPAP and digitalis treatment could finally be discontinued. After this his course was uneventful; chest $x$-ray normalized, he gained in weight, and was discharged aged 13 weeks. At age 4 months psychomotor development was normal.

Echocardiography. Echocardiography employed a technique previously described (Lundström, 1974) using a Smith-Kline Ekoline 20 Ultrasonoscope and a $5 \mathrm{MHz}$ unfocused transducer. Polaroid photographs of the time-motion display were taken from a slave storage oscilloscope (Tektronix 603). On the echocardiogram measurements were made of the aortic root diameter (Ao) and the left atrial dimension (LA) at end systole, defined as the point of maximal forward movement of the aortic root (Fig. 1). The ratio LA/Ao was used to assess left atrial size, and thereby indirectly shunt flow (Silverman et al., 1974).

In a group of 34 premature infants without clinical or $x$-ray evidence of cardiac disease, 54 measurements of LA/Ao ratio were performed with consecutive examinations at different weight levels. For this normal group we found a mean LA/Ao ratio of $1 \cdot 12 \pm 0 \cdot 28(2 \mathrm{SD})$.

Our patient was examined by echocardiography initially at the age of 3 days, again when the systolic murmur appeared, and then several times during the 